\title{
The Effectiveness of Stimulus to the Language Acquisition of Early Age Child
}

\author{
Nuraini Kasman \\ Indonesian Education Program, Teachers Training and Education College of Sidrap, Indonesia \\ Syahruddin Kaseng \\ Postgradute Program of Makassar State University, Indonesia \\ St. Hawang Hanafie \\ Postgradute Program of Makassar State University, Indonesia \\ Kembong Daeng \\ Language and Literature Faculty of Makassar State University, Indonesia
}

\begin{abstract}
The present study was triggered by a variety of aspects in language education which need our urgent attention. One of these aspects is language acquisition that is related to the developmental stages of children. The early age child phase is a critical period for the development of children. This study aims to determine: (1) Significant effects before and after the stimulus to language vocabulary acquisition early childhood; (2) Knowing the development of child language acquisition at age four when viewed from the aspect of vocabulary acquisition, and (3) Knowing whether the respondent is still to generalize the meaning of objects that have the same characteristics. The theory underlying the research is based on B.F. Skinner's theory of behaviorism.
\end{abstract}

Index Terms —stimulus, language acquisition, pre-schoolchildren, behaviorism

\section{INTRODUCTION}

\section{A. The Urgency of Language Acquisition Research}

One of of education language aspect that need attention is language acquisition. However, research on early childhood language acquisition, especially in Indonesia is still very rarely done, so until the current theories relating to language acquisition are still using the theories presented by experts coming from the west.

The development of child language acquisition begins from the development of comprehension; phonological development; syntactic development; morphology development; and vocabulary development (Goodluck, 1996). Based on the opinion above it can be said that the scope of the child language acquisition research is a developmental stage of comprehension; phonological development; syntactic development; morphology developmental; and vocabulary development.

Growth and early development of children is a phase that need attention. Phase of early childhood is a critical period for a child. If this critical period given stimulus intensive input form of intelligence, aspects of language and other aspects, is likely to be obtained very great human quality when compared with no stimulus intensive.

\section{B. The Views of Nativism and Behaviorism in Language Acquisition}

In theory there are two views of language acquisition is very popular, that is Nativism view and the view of Behaviorism. According to the views of nativism, the language is too complex and impossible to learn in a short time through methods such as imitation. Thus, some important aspects regarding the language system in humans would have no natural. Chomsky ( 1965) was not only impressed by the complexity of the language, but also by some of the many errors and irregularities in the rules of pronunciation (performance). Thus it is possible that human language learning (first) of another human being, during which they learn to use the principles that guide him compile grammar. Learning a language is just fill in the details in the existing structures in nature (Purwo, 1993, p.97).

Nativism view assumes that language behavior is innate. Thus, children in acquiring language is not influenced by the stimulus from outside of the child. They say that every child who has a three-year-old has been able to speak as adults do. Furthermore, Chomsky (1969) states that every child has been equipped with language acquisition device (LAD). This tool is an administration that has biological features of a grammar program. Language acquisition device is a special physiological brain to process language. This tool enables the child to acquire language without obtaining input from the surrounding nature. Based on the above, it means that every child is born with the universality of linguistic structures 'that have been fused'. That is, the child does not have to learn the common characteristics of the 
structure of all human languages, as a child born with a framework of linguistic structure (semantic, syntactic, and phonological ) in born.

The Saxon behaviorism found that child language acquisition is not an innate as indicated by the nativism. Behaviorism view emphasized that the process of language acquisition (first) controlled from outside, that is by stimuli presented via the environment. Language is one of the other behaviors. Thus, according to the behaviorism language terms is less precise because conotate the entities, something that is owned or used and not something that is done. For the term of language they prefer to use the term verbal behavior (Purwo, 1993, p.97).

When observed both views on child language acquisition is mutually supportive. The opinion must be integrated, because without the LAD or language acquisition device, then the child will not be able to process the input elements of the language environment. Conversely, if the inputs in the form of the language elements are not derived from the child's environment, then the child will not be able to speak automatically.

\section{Vocabulary of Four-year-olds}

When referring to the behaviorism approach, the development of the child's vocabulary acquisition depends on the inputs it receives. This is also confirmed Dardjowidjojo for researching grandson named Echa. The number and kind of controlled vocabulary Echa really depends on the input he received the research results as well as "guestimate" the number of words in the child mastered certain ages vary widely. Lock (1995) states that at the age of 1.6 years up to 1.8 years of a child control about 50 words (p.361). Instead, Benedict (1979) and Corrigan (1978) (in Garman 1981, p.183) states that this number has been reached at the age of approximately 1.2 years and 1.3 years. In the graph, Moskowitz (1981, p.124) shows that at the age of 1.6 years the child has mastered about 100 words, and this number rose to about 275 by the age of 2.0 years. Dromi, which examines the development of their children, Keren, mastering Hebrew (1987, p.110), reported that Keren has mastered 337 words at the time she was 1.5. Smith's research (in Garman, 1981, p.196) shows the number a little under 500 words by the age of 2.6 (Dardjowidjojo, 1997, p.27). Thus, it can be seen that the mastery of vocabulary of children varies. This is due to the inputs received by children of different frequencies, and the situation was different.

According to Clark (1995, p.13) vocabulary productive adults is approximately 20,000 - 50000 word forms, while komprehensinya much greater than that amount. For children aged 6.0 years has mastered the vocabulary of approximately 14,000 . Since the age of 2.0 years, a child's vocabulary will grow by 10 vocabulary every day. Thus, it is known that the child will master a vocabulary of 3,650 per year. So the our-year-olds have mastered a vocabulary of 7300. Dardjowidjoyo (2000, p.262) found language acquisition grandchildren Echa 328 nouns, 215 verbs, 106 adjectives and 85 function words. Furthermore, he stated that the child's vocabulary development is influenced by many external factors. He believes that the procurement of the word 'computer' by Echa, and not controlled by Teguh, their attendants children aged 3.8 years, is solely due to environmental factors.

\section{Stimulus - Response}

Since human is born into the world is not necessarily being smart. Humans still need to learn in order to be smart. In achieving an intelligence the human requires a stimulus from the environment. So is the ability to speak of a human child is not an innate. Although the potential to speak is already exists in human, but in the absence of social interaction or stimulus from the environment, then people will not be able to develop the potential of the talk that he already has. The ability to speak is not only a generation of something that has been present in the original nature, but also a social phenomenon. Even if there is a predisposition in humans similar structurally to speak, but the language or words specifically controlled by a person depends on the social opportunity to learn (Whitherington 1984, p.130).

The stimulus is an important factor in learning. Similarly, in early childhood language acquisition. With a stimulus to children who are learning the language, the child's language development can be controlled. Soemanto (1998, p. 126) states that if the student does not show any reaction to the stimulus, the teacher may not be able to guide his behavior toward behavior. Based on the above, it can be said that the stimulus is an important factor that can assist children in learning. Similarly, early childhood who are learning the language, of course, need to get the stimulus, so that language development is increasing rapidly. Without intensive stimulus to children who are learning language, the development of children's vocabulary acquired will evolve as it is, and it is difficult to control.

\section{E. Related Research}

Andriyani (2009), with the finding that the more intensive environment gives the stimuli, the more rapid development of the preschool child language acquisition.

Samaah (2008), concluded that the sentence aspect plays an important role in childhood language to the language skills in adults.

Hairuddin (2007), with findings of (1) there is a general sequence in Indonesian sentence acquisition by the four groups of the study sample and (2) there was no difference in the order of acquisition of significant Indonesian sentence among the four groups.

Yulianto (2001), found the characteristic sounds of language children aged 0;1-2; 6 years and type of phonological sequence in three stages of development. 


\section{RESEARCH METHOD}

\section{A. Types and Research Approach}

This research is a kind of exploratory research using qualitative approaches in analytic - synthetic.

\section{B. Focus Research}

The focus of this research is early childhood language acquisition. This study examines the acquisition of vocabulary and semantic four years of age enrolled in group play of TK Aisyiyah Kadidi Village, District Pancarijang Sidenreng Rappang.

\section{Data and Data Sources}

The data in the study is vocabulary acquisition and mastery of semantic in early childhood. The data in question will be obtained / or sourced from 15 four -year olds who actively follow the education in group play of TK Aisyiah Kadidi Village, District Pancarijang Sidenreng Rappang.

\section{Overview of Respondents}

The respondents of this study are listed early childhood kindergarten play groups Aisyiyah Kadidi Village, District Pancarijang Sidenreng Rappang. Age of the respondents an average of four years. Age their children have started to learn the language intensively, so that the development of their vocabulary develops rapidly when compared with younger children in under four years.

Based on observations and interviews with parents of respondents, obtained information that the majority of respondents have introduced or taught letter names. So, there has been among the respondents who knew some of the letters, although still not really speak it fluently and has not been able to recognize the letters correctly.

The environment in which they play on a daily basis is not much different. That is why, vocabulary inputs they receive relatively the same. As far as the authors, their ability to recite vocabulary they produce are not much different from one another. This indicates that respondents of this study did not have significant differences in pronouncing vocabulary, so that their vocabulary acquisition in the process of receiving stimulus provided is not much different.

\section{E. Data Collection Methods and Research Instrument}

To obtain the data of this study, used data collection methods include questionnaire (in the form of picture) and interview. The picture were designed in such a way that appeals to the respondent. The selection of picture as the study data collection instrument is passed, due to the early childhood objects in the pictures will always be worth a look. The use of these pictures will stimulate young children to respond. To determine whether the respondent is to generalize the objects that have the same characteristics, then designed a number of object picture that have the same characteristics as a means of collecting data.

\section{F. Data Collection Procedures}

There are several steps taken in this study the data collection efforts. These steps are the pre-test, reinforcement, and final test. Pre-tests intended to determine the acquisition of vocabulary and understanding of the meaning of the objects become instruments for collecting data by respondents. In this pre-test, asked what the names of objects contained in the pictures of this research instrument as a picture of the beginning of early childhood language acquisition. Reinforcement is the process of providing stimulus to the respondent to show pictures into the instrument. The stimulus lasted for three times. Allocation of time each stimulus was 120 minutes. The study was conducted in the morning between the hours of 8:00 to 10:00 a.m. After completion of the stimulus, the next step the final test. The final test aims to determine the progress of the development of vocabulary and language acquisition respondents. Giving the final test at the same time is the final step for data collection of this study.

\section{G. Data Analysis Techniques}

In analyzing the data, researchers used an inductive method. In this case, researchers still adhere to the information that has been obtained from the field, and then analyzed based on the theory and framework as described earlier. Analysis of these data include respondents' language acquisition in terms of the development of semantics and vocabulary development.

Sebelum pemberian stimulus kepada responden terlebih dahulu diberikan tes awal untuk mengetahui pemerolehan kosakata dan pemerolehan semantik responden. Setelah itu barulah diberikan stimulus kepada responden. Sedangkan untuk mengetahui pemerolehan kosakata dan pemerolehan semantik responden setelah pemberian stimulus, maka dilakukan tes akhir.

Before giving a stimulus to respondent the first granted pre-tests to determine the acquisition of vocabulary and semantic acquisition respondents. Afterwards, the stimulus given to the respondent. Whereas for knowing the vocabulary acquisition and the acquisition of semantic respondents after the stimulus, then the final test given.

As a guideline scoring against the respondents' answers, then made the following guidelines:

a. Respondents guess picture research data collection instruments correctly and smoothly (Smt), the score is 5 .

b. Respondents guessed correctly picture research instruments but substandard (G.S.), the score is 4 . 
c. Respondents guess instruments picture mentioned research by syllable only ( $\mathrm{Slbl}$ ), the score is 3 .

d. Respondents guess image research instruments with another name (A.N.), the score is 2 .

e. Respondents did not respond or said do not know (N.R.), the score is 1 .

\section{H. Problem Statements}

The question in this study is as follows.

1. Are there any significant effect before and after the stimulus to language vocabulary acquisition of early childhood?

2. How is the development of child language acquisition at age four when viewed from the aspect of vocabulary acquisition?

3. Whether the respondent was to generalize the meaning of objects that have the same characteristics?

\section{RESULTS AND DISCUSSION}

Data processing research started from the pre-test data processing. Respondents are given a score as pointed out above. The scoring is intended to obtain quantitative data analysis. Processing of data is grouped into two, namely the processing of data vocabulary acquisition and processing semantics acquisition.

\section{Vocabulary Acquisition in Early Childhood}

Vocabulary tested include ten groups, namely (1) the picture of animals which comprised over cows, ducks, goats, sheep, dogs, cats, chickens, horses, and rabbits; (2) the picture of wild animals, including lions, wolves, tigers, elephants, chimpanzees, zebras, giraffes, snakes, kangaroos, crocodiles, (3) the picture of fish and insects, namely fish, shrimp, squid, crabs, dragonflies, flies, ants, mosquitoes, caterpillars, (4) the picture of fruits, including watermelon, papaya, oranges, strawberries, mango, banana, coconut, apple, and durian; (5) the picture of vegetables and spices include string beans, eggplant, carrots, cabbage, corn, kale, chilli, pepper, garlic, onion, and tomatoes; (6) the picture of stationery and school supplies consisting of books, pens, pencils, rulers, printer, handbags, shoes, shirts, and clothing; (7) the picture of electronic equipment / technology ie television, radio, refrigerator, strika, computers, laptops, tablets, dispensers, play station, (8) the picture of the term telecommunication covers online, loading, internet, games, movies, soap operas, access, (9) the relative term consisting of father, mother, brother, sister, grandmother, Kakae, uncle, aunt, cousin; (10) transportation picture consist of aircraft, buses, trains, marine vessels, buggy, tricycle, helicopter, motorcycle; (11) professions picture include teachers, police, soldiers, doctors, nurses, drivers, pilots, and lecturer.

1. Vocabulary Acquisition in Pre-tests

Results of pre-test data is shown in the table below.

TABLE 4.1:

ACQUISITION OF EARLY CHILDHOOD VOCABULARY AT THE PRE-TEST

\begin{tabular}{|c|c|c|c|c|c|c|c|c|c|c|c|}
\hline \multirow{3}{*}{$\begin{array}{l}\text { The Answere } \\
\text { Alternative }\end{array}$} & \multicolumn{11}{|c|}{ Vocabulary group } \\
\hline & W.A. & F.A. & Fs. \& In & V.S. & Frt & $\mathrm{St}$ & Elc. & I.T. & & trns & Prfs \\
\hline & $\%$ & $\%$ & $\%$ & $\%$ & $\%$ & $\%$ & $\%$ & $\%$ & $\%$ & $\%$ & $\%$ \\
\hline a. W.S. & 10 & 13 & 24 & 10 & 23 & 15 & 12 & 13 & 25 & 20 & 20 \\
\hline b. G\&S & 45 & 28 & 24 & 25 & 30 & 26 & 22 & 26 & 25 & 26 & 23 \\
\hline c. Slb & 5 & 3 & 2 & 2 & 5 & 4 & 4 & 3 & 4 & 6 & 3 \\
\hline d. A.N & 20 & 44 & 15 & 27 & 14 & 22 & 27 & 22 & 22 & 24 & 24 \\
\hline e. N.R. & 20 & 12 & 35 & 36 & 28 & 33 & 35 & 36 & 24 & 24 & 30 \\
\hline Jumlah & 100 & 100 & 100 & 100 & 100 & 100 & 100 & 100 & 100 & 100 & 100 \\
\hline
\end{tabular}

The description of abbreviations in the table:

W.A.: wild animals

F. I.: fish and insect

F.: fruits

Elc.: electronic equipment

Rltv: relative

Prfs: profession

G \& S: good and substandard

A.N.: another name

The data in Table 4.1 shows that in guessing the farm animal picture at pre-test (before the stimulus) only $10 \%$ of respondents who guessed well and smoothly, $45 \%$ who responded well and less well, $5 \%$ answered with syllables alone, $20 \%$ answered another name, and $20 \%$ do not know. Furthermore, in guessing the wild animal picture there were $13 \%$ respondents who answered smoothly, $18 \%$ good and substandard, 3\% answered with syllables alone, 44\% answered another name, and $12 \%$ do not know. Furthermore, in guessing the picture of fish and insects there were $24 \%$ respondents who answered smoothly, 24\% good and substandard, 2\% answered with syllables alone, 15\% answered another name, and 35\% do not know. Furthermore, in guessing the picture of vegetables and spices there are $10 \%$ of respondents who answered smoothly, 25\% good and substandard, 5\% answered with syllables alone, 25\% answered another name, and $47 \%$ do not know. Furthermore, the images of fruits guess there are $25 \%$ of respondents who 
answered smoothly, 30\% good and substandard, 5\% responded with syllables alone, $14 \%$ answered another name, and $28 \%$ do not know. Furthermore, the image of stationery guess there are $15 \%$ of respondents who answered smoothly, $26 \%$ good and substandard, $4 \%$ answered with syllables alone, $22 \%$ answered another name, and 33\% do not know. Furthermore, the electronic appliance image guessing there are $12 \%$ of respondents who answered smoothly, $22 \%$ good and substandard, $4 \%$ answered with syllables alone, $27 \%$ answered another name, and 35\% do not know. Furthermore, the guess image information and telecommunication apparatus, there were 13 respondents who answered smoothly, $26 \%$ good and substandard, 3\% answered with syllables alone, 22\% answered another name, and 36\% do not know. Furthermore, in terms of kinship picture guessing there are $25 \%$ respondents who answered smoothly, $25 \%$ good and substandard, $0.3 \%$ answered with syllables only, $2 \%$ answered another name, and $1.23 \%$ who do not know. Furthermore, the transportation picture guessing there are $3.2 \%$ of respondents who answered smoothly, $2 \%$ well and less well, $2 \%$ answered with syllables alone, $40 \%$ answered another name, and $2 \%$ who do not know. Furthermore, in terms of kinship picture guessing there are $25 \%$ of respondents who answered smoothly, $25 \%$ good and substandard, $4 \%$ answered the first syllable, $22 \%$ answered another name, and $24 \%$ do not know. Furthermore, the image profession professions guess there are $20 \%$ who responded well and smoothly, 23\% who responded well and less well, $3 \%$ answered with syllables alone, $24 \%$ answered another name, and $30 \%$ do not know.

\section{Vocabulary Acquisition in Final Test}

Data acquisition early childhood vocabulary at the end of the test. Meant the end of the test data can be seen in the following table.

TABLE 4.2

ACQUISITION VOCABULARY OF EARLY CHILDHOOD AT THE END OF THE POS-TEST

\begin{tabular}{|c|c|c|c|c|c|c|c|c|c|c|c|}
\hline \multirow{2}{*}{$\begin{array}{l}\text { The Answere } \\
\text { Alternative }\end{array}$} & \multicolumn{11}{|c|}{ Vocabulary group } \\
\hline & W.A. & F.A. & Fs. \& In & V.S. & Frt & $\mathrm{St}$ & Elc. & I.T. & & trns & Prfs \\
\hline & $\%$ & $\%$ & $\%$ & $\%$ & $\%$ & $\%$ & $\%$ & $\%$ & $\%$ & $\%$ & $\%$ \\
\hline a. Smt & 74,28 & 74,28 & 75,24 & 76,27 & 80,0 & 80,14 & 78 & 78 & 98,81 & 98,81 & 96,93 \\
\hline b. G\&S & 0,14 & 0,14 & 24,76 & 23,73 & 20 & 12 & 12 & 0 & 1,12 & 1,12 & 0 \\
\hline c. Slb & 0,07 & 0,07 & 0 & 0 & 0 & 0 & 0 & 0 & 0,07 & 0,07 & 0,07 \\
\hline d. A.N & 25 & 25 & 0 & 0 & 0 & 7,86 & 7,86 & 22 & 0 & 0 & 0 \\
\hline e. N.R. & 0,07 & 0,07 & 0 & 0 & 0 & 0 & 0 & 0 & 0 & 0 & 0 \\
\hline Total & 100 & 100 & 100 & 100 & 100 & 100 & 100 & 100 & 100 & 100 & 100 \\
\hline
\end{tabular}

The data in Table 4.1 shows that the picture of farm animal guess at the post-test there were $74.28 \%$ of respondents who guessed well and smoothly, $0.14 \%$ who responded well and substandard, $0.07 \%$ answered with syllables alone, $25 \%$ menawab another name, and $0.07 \%$ who do not know. Furthermore, the picture of wild animals are guessing $74.28 \%$ of respondents who answered smoothly, both $0.14 \%$ and less smoothly, $0.07 \%$ answered with syllables alone, $25 \%$ answered another name, and $0.07 \%$ were do not know. Furthermore, the fish picture and insects guess there are $75.24 \%$ of respondents who answered smoothly, $24.76 \%$ good and substandard, $0 \%$ answered with syllables only, $0 \%$ answered another name, and $0 \%$ who do not know. Furthermore, the picture of vegetables and spices guess there are $76.27 \%$ of respondents who answered smoothly, $23.73 \%$ good and substandard, $0 \%$ answered with syllables only, $0 \%$ answered another name, and 0\% who do not know. Furthermore, the picture of fruits guess there are $80.0 \%$ of respondents who answered smoothly, 20\% good and substandard, $0 \%$ answered with syllables only, $0 \%$ answered another name, and $0 \%$ who do not know. Furthermore, the picture of stationery guess there are $80.14 \%$ of respondents who answered smoothly, $12 \%$ good and substandard, $0 \%$ answered with syllables alone, $7.86 \%$ answered another name, and $0 \%$ who do not know. Furthermore, the electronic picture guessing there are $78 \%$ of respondents who answered smoothly, $12 \%$ good and substandard, $0 \%$ answered with syllables alone, $7.86 \%$ answered another name, and $0 \%$ who do not know. Furthermore, the guess image information and telecommunication apparatus contained $78 \%$ of respondents who answered smoothly, $0 \%$ good and substandard, $0 \%$ answered with the first syllable, $22 \%$ answered another name, and $0 \%$ who do not know. Furthermore, in guessing the picture there is a kinship term 98.81 respondents who answered smoothly, both $1.12 \%$ and less smoothly, $0.07 \%$ answered with syllables only, $0 \%$ answered another name, and $0 \%$ who do not know. Furthermore, the transportation picture guessing there are $98.81 \%$ of respondents who answered smoothly, both $1.12 \%$ and less smoothly, $0.07 \%$ answered with syllables only, $0 \%$ answered another name, and $0 \%$ who do not know. Furthermore, in guessing the picture there is a kinship term $96.93 \%$ of respondents who answered smoothly, $0 \%$ good and substandard, $0.07 \%$ answered with syllables only, $0 \%$ answered another name, and $0 \%$ who do not know.

\section{Semantics Acquisition in Early Childhood}

Based on the data obtained the picture of objects which turned out to have similar characteristics of respondents always generalizable. When pre-tests to the respondents with the material 'group animals' apparently they do generalize to mention 'geese' and 'grouse' as a picture of 'duck'; 'buffalo' hypothesized the same with 'cow'. This shows that they have not been able to distinguish the types of 'animals'. Based on these data, it can be said that the four years children are still not able to distinguish objects that are almost similar in shape. Likewise, when some kind of plane picture that is 'plane', 'helicopter', 'fighter'. According to the respondents were asked the third picture is a picture of 'helicopter'. Although the stimulus has been awarded three times, but they still say that the picture is a picture of 'helicopter'. They really generalize. Why are they difficult to understand the picture? The answer is, first, the pictures are very similar, 
both, the people who were in the neighborhood they almost never mention the name of the object. Referring to the data, if the respondents have incorporated the word to the lexicon, it is necessary to more intensive stimulus to change their opinion about the object. Furthermore, when shown wild animals picture that is 'lion' and 'wolf'. They guess the pictures by 'tiger'; 'giraffe' and 'zebra' they call 'horse'. They also do the same hypothesis for the picture of 'rhinos' and 'bull'. Similarly, the picture of insects that 'ant', 'mosquito', and 'flies'. They generalize the three picture with the name 'mosquito'. While the name of the fish 'whales, sharks, dolphins, and the fish they call 'dolphin'. Subsequently, the name of the vegetables they know just 'bean', 'maize', 'swamp', 'cabbage', and 'carrots'. To spice the image name, the respondent only knows chilli, garlic, and onion. Furthermore, picture of fruit they hypothesize that the same is 'papaya' and 'watermelon', 'pear' and 'nuts'. For pictures of stationery, respondents hypothesized pencil, pen, and boardmarker and call them 'pen'. Furthermore, for electronic equipment, computer hypothesized respondents with a television, a 'fridge' with 'dispenser'. Furthermore, the picture of tools and telecommunications terms of respondents are familiar with the term online, loading, internet, but they have not been able to explain its meaning. For images showing kinship respondents already know and understand well the term 'father', 'mother', 'brother', 'sister', 'grandfather', 'grandmother', 'uncle', and 'aunt' but they are not familiar with the term brother-in-law, and grandchildren. Furthermore, for the term profession, respondents have understood the meaning of teachers, policemen, soldiers, pilots, and a driver.

Based on the observations made, it turns out the characteristics of the respondents saw the object possessed almost the same. Therefore, they have not been able to distinguish the image correctly. In addition to the characteristics of generalized objects are very similar, another factor that makes the respondents do not know the actual name of the image of sheep, geese, grouse, buffalo, watermelon, pear, sharks, whales, they have received no feedback about the vocabulary. Meanwhile, the other pictures they have often seen either on television or in books.

\section{CONCLUSIONS AND RECOMMENDATIONS}

Based on the analysis of research data and in response to the formulation of research problems, it can be concluded as follows.

1. There is a significant effect of stimulus before and after administration of the early childhood vocabulary acquisition, amounting to an average of $50 \%$ in each group were tested vocabulary. That means stimulus is accompanied by a positive reinforcement effect in early childhood language acquisition.

2. Vocabulary development of early childhood at the age of four years to reach 7000 words.

3. In terms of semantics acquisition, early childhood is to generalize to objects that have the same characteristics.

4. The more intensive environmental stimulus, the more rapid development of early childhood language acquisition, both in terms of vocabulary and semantic terms.

\section{REFERENCES}

[1] Andriany, Liesna. (2009). Pengaruh Stimuli terhadap Pemerolehan Bahasa Anak Prasekolah. Jurnal Linguistik Indonesia, 27,( 1).1-95. (http://www.e-li.org/Pages/Current-Issue.aspx?docname=/publish. Diakses 13 Februari 2012).

[2] Atkinson, L. Rita, et al. (1999). Pengantar Psikologi Jilid 2 (diterjemahkan oleh Nurjannah). Jakarta: Erlangga.

[3] Bennett-Kastor, Tina. (1988). Analyzing Children,s Language Methods and Theories. Oxford: Basil Blackwell.

[4] Bloom, Lois, Margaret Lahey.(1978). Language Development and Language Disorders. Canada: John Wiley \& Sons Inc.

[5] Chaplin, J.P. (1999). Kamus Lengkap Psikologi (diterjemahkan oleh Kartini Kartono). Jakarta: P.T. Raja Grafindo Persada.

[6] Chomsky, Carol. (1969). The Acquisition of Syntax in Children from 5 to 10. Cambridge: Mass. M.I.T. Press.

[7] Chomsky, Noam. (1965). Aspect of the Theory of Syntax. Cambridge: Mass. M.I.T. Press.

[8] Clark, Eve V. (1995). "Later Lexical Development and Word Formation." Dalam Fletcher \& Mac Whinney.

[9] Cook, Vivian. (1996). Second Language Learning and Language Teaching. New York: Oxford University Press.

[10] Dardjowodjojo, Soenjono. (2000). Echa: Kisah Pemerolehan Bahasa Anak Indonesia. Jakarta: PT. Grasindo.

[11] Dromi, Esther. (1987) Early Lexical Development. Cambridge: Cambridge University Press.

[12] Ellis, Rod. (1985). Understanding Second Language Acquistion. New York: Oxford University Press.

[13] Garman, Michael. (1981). Language Acquisition Studies and First Language Development: Cambridge: Cambridge University Press.

[14] Goodluck, Helen. (1996). Language Acquistion: A Linguistic Introduction. Massachusetts USA: Blackwell Publishers Inc.

[15] Hairuddin. (2007). Urutan Pemerolehan Kalimat Bahasa Indonesia Murid Sekolah Dasar Kota Palembang. Forum Pendidikan, 20 (2), 99-112.

[16] Hall, S. Calvin \& Gardner Lindzey. (1993). Teori, Sifat dan Behavioristik. (diterjemahkan oleh A. Supratikna). Yogyakarta: Kanisius.

[17] Kaseng, Syahruddin, dkk. (1986). Pemerolehan Struktur Bahasa Anak-Anak Prasekolah (Ekabahasa Bugis). Jakarta: Perum Balai Pustaka.

[18] Kiparsky, P. (1983). “From Cyclic Phonology to Lexical Phonology.” In H. Van der Huist and N. Smith, eds, The Structure of Phonological Representation, part 1. Dordrecht: Foris. Lindfors, Wells, Judith. 1980. Children's6Language and Learning. London: Applied Science Publishers Ltd.

[19] Lindfors, Wells, Judith. (1980). Children's Language and Learning. London: Applied Science Publishers Ltd.

[20] Lock, John L. (1995). The Child's Path to Spoken Language. Cambridge: Harvard University Press.

[21] Moskowitz, Breyne Arlene. (1981). The Acquisition of Language. In Wang 1981.

[22] Nababan, Sri Utari Subiyakto. (1992). Psikolinguistik Suatu Pengantar. Jakarta: PT. Gramedia Pustaka Utama. 
[23] Purwo, Kaswanti Bambang, et al. (1996). Pelbba 9. Jakarta: PN. Balai Pustaka.

[24] Soemanto, Wasty. (1998). Psikologi Pendidikan. Jakarta: P.T. Rineka Cipta.

[25] Tarigan, Henry Guntur. (1984). Psikolinguistik. Bandung: Penerbit Angkasa.

[26] Whitherington. (1984). Psikologi Pendidikan (diterjemahkan oleh M. Buchori). Jakarta: Penerbit Aksara Baru.

[27] Yulianto, Bambang. (2001). "Perkembangan Fonologi Tuturan Bahasa Indonesia Anak: Suatu Tinjauan Berdasarkan Fonologi Generatif.” Disertasi. Malang: PPs Program Studi Pendidikan Bahasa PPs Universitas Negeri Malang.

Nuraini Kasman, the student of Makassar State University and the lecturer of Indonesian Education Program,, Teachers Training and Education College of Sidrap. She has been teaching linguistics since 2003. She had been the head of Indonesia Education Program in 2001-2008 and she has been the head of English Education Program Teachers Training and Education College of Sidrap since 2010-2014

Syahruddin Kaseng a doctor in literature and a professor of linguistics. He is the lecturer at Postgraduate Program of Makassar State University. He is the first doctor at Ujung Pandang Teacher Training and Education Institute. He was the manager of Ujung Pandang Teaching and Education Institute in 1991-1994.

St. Hawang Hanafie, a doctor and professor of linguistics and the lecturer at Postgraduate Program of Makassar State University. She had been the head of Language and Literature Education Faculty and the head of LPPM Ujung Pandang, Teacher Training and Education Institute.

Kembong Daeng, a doctor of linguistics and the lecturer at Indonesian Department, Language and Literature Faculty of Makassar State University. She is the head of Language Laboratory at Language and Literature Faculty, of Makassar State University. 